\title{
NOTES ON AN EARLY DAGUERREOTYPE OF WALT WHITMAN
}

\author{
Denise B. Bethel
}

ON a RECENT TRIP to the Walt Whitman Historic Site in Camden, New Jersey, I was given the opportunity to examine the early daguerreotype of Whitman located there. ${ }^{1}$ This superb portrait (Saunders \#1.1; $W W Q R-1840$ s, \#2), showing the poet in frock coat and black cravat, may be the earliest photograph of Whitman extant and has been reproduced many times. ${ }^{2}$ Whitman scholarship traditionally assigns this image to Whitman's New York newspaper days, during the author's stints on, say, the New York Aurora or the Brooklyn Eagle, with suggested dates ranging from the early to late $1840 \mathrm{~s}^{3}$ In the image of Whitman presented-a serious young man, dressed in the style of the day, with one lock of hair turning prematurely grey - there is nothing to contradict this. After a brief survey of Whitman daguerreotype portraits, ${ }^{4}$ however, I was struck by the absence of information regarding the physical attributes of this and other daguerreotypes of the author: what the plate sizes might be, how the images are cased or framed, what markings might be present that would be meaningful to an historian of nineteenth-century photographs, markings that might have been overlooked by literary scholars. My examination of the early Whitman daguerreotype in Camden yielded surprising results. Based on my knowledge of American daguerreotypes, and how they were made, I propose that the Camden portrait of Whitman was not taken in New York, but in New Orleans, and thus can be dated precisely to that period of February to May, 1848, when Whitman was 28 years of age.

First, a description of the Camden daguerreotype in standard photographic terms: the portrait is a half-plate, ${ }^{5}$ housed in a mahoganycolored passe-partout mount ${ }^{6}$ and gilt wall frame. The size of the image, framed by the oval mat window, is slightly larger than quarter-plate size (sight size $47 / 8 \times 3 \frac{1}{2}$ inches), although the edges of the image extend beyond the mat opening, thus bringing the total plate size to that of a half-plate (approximately $51 / 2 \times 4 \frac{1}{4}$ inches). The daguerreotype is not presented in a case, as one might expect of a New York daguerreotype of the 1840s, but rather in a mahogany-colored glass passe-partout mount, measuring $63 / 8 \times 5$ inches, with gilt-edged window and a single gilt-ruled decorative border. The mount and its cover glass are sealed together, as is customary for daguerreotypes housed in this way, with matching mahogany-colored paper edging; the daguerreotype plate itself 


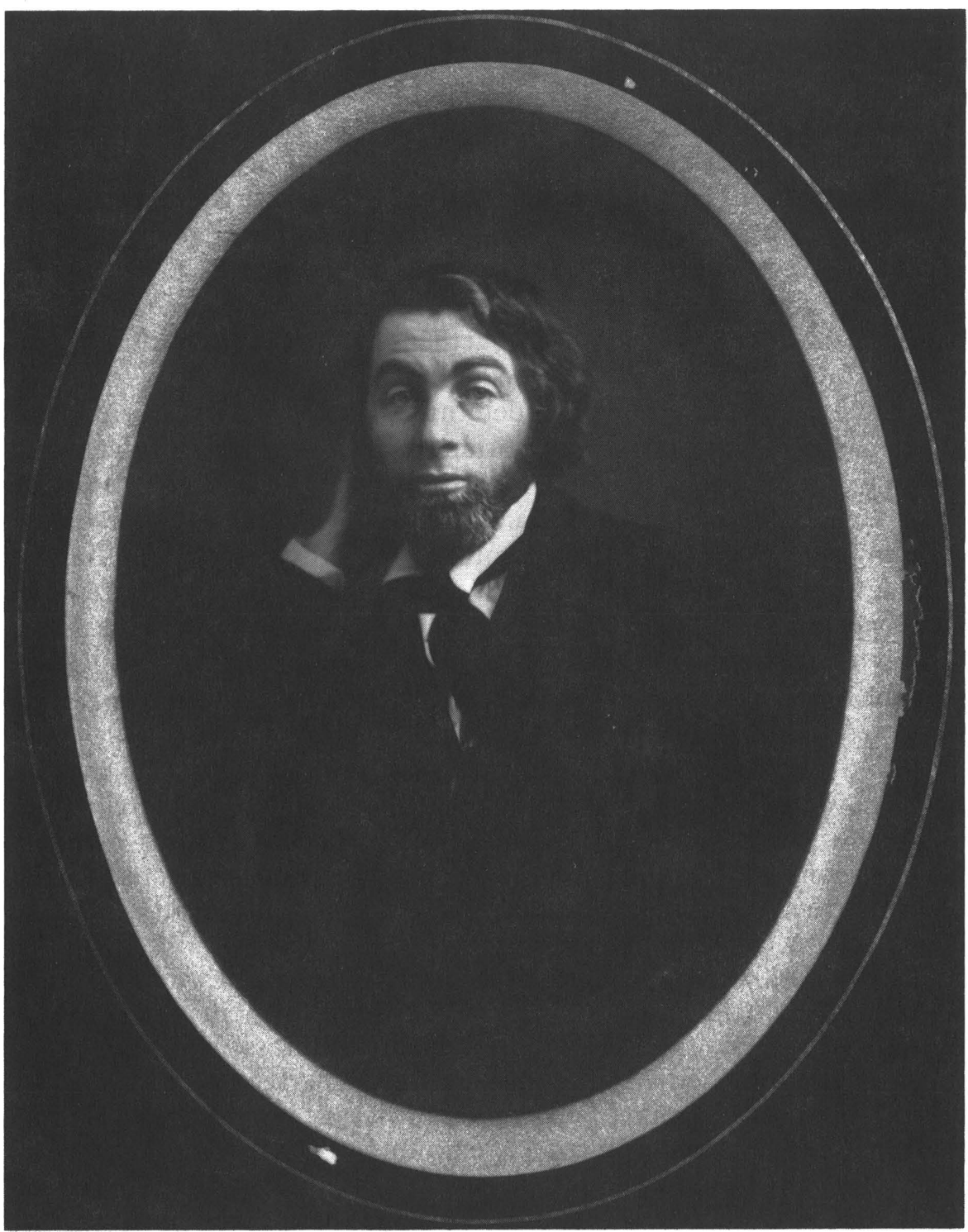

1848 Daguerreotype of Walt Whitman. 
is sealed to the verso of the mount's card backing with paper strips, as was also common; covering the daguerreotype plate is a rectangle of brittle card, affixed to the back of the mount with further paper scraps. In my opinion, this passe-partout mount and its various paper seals are contemporary with the daguerreotype itself and are likely original. Although portions of the paper seal around the card covering the daguerreotype plate are beginning to split from age, the edges of this seal are largely undisturbed and show no signs of tampering.

The whole daguerreotype "package"-i.e., the daguerreotype plate, mount, and cover glass, sealed together-now is displayed in a gilt wooden frame with unmarked wooden backing. Although this frame is not new, it would be difficult to determine whether or not it is original to the piece, but this is a less important matter. As it is not attached in any way to the original daguerreotype package, the frame could be exchanged easily, even now, for another period frame of the same size, with no one the wiser. When I examined the daguerreotype, the frame's wooden backing was held in place by four small modern nails that were not at all rusted and hence quite easily removed, a sign that the frame had not remained undisturbed for decades. In this instance, fortunately, only the original daguerreotype package, with its mount and paper seals, was important for my purposes.

To a photographic historian, the first indication that the portrait might not have been made in New York City is the passe-partout mount in which the daguerreotype plate is housed. A mount of this nature is found customarily on European daguerreotypes, and more specifically, on daguerreotypes made in France. These mounts are sometimes made of paper, but more often are of glass, painted or varnished on the reverse in dark colors such as black or mahogany. They are typically larger than the daguerreotype plates they frame. American daguerreotypes, by contrast, are almost always found in brass mats that correspond in size to the outer dimensions of the daguerreotype plate and are housed in specially constructed miniature cases. In Whitman's time, these cases were made of wood covered in embossed paper or leather, with velvet or satin linings. The so-called "Christ likeness" of Whitman (Saunders 5, WWQR-1850s, \#3), a daguerreotype now in the Oscar Lion Collection of the New York Public Library, conforms exactly to this "American formula": the oval brass mat matches the quarter-plate size of the image; the whole is housed in a quarter-plate-sized leathercovered case with floral design. When American daguerreotypes were framed for wall display, as they occasionally were, the standard brass mats usually remained on the images. This is not to say that American daguerreotypes are never, under any circumstances, found in passepartout mounts; or that French daguerreotypes are never, under any circumstances, found in cases. From a daguerreotype connoisseur's 
perspective, however, a passe-partout mount is typically European, and more often than not, French in origin.

As Whitman never traveled to Europe, it seems a fair guess that the daguerreotype could have been made in a part of the United States where European materials, and a European aesthetic, would govern the choice of a daguerreotype's housing. In the 1840s, in New Orleans, there were dozens of daguerreotypists of French and German descent plying their trade. ${ }^{7}$ Some, like the free man of color Jules Lion (c. 1816-1866), had been born in France; others, with names such as Charles Peyroux, or Auguste Dubar, or P. Langlumé, appear fleetingly in New Orleans city directories, and we can only surmise their histories. Further research is needed to determine-if, indeed, a determination is possible-who in New Orleans might have taken the portrait. Suffice it to say that for an historian of daguerreotypes, the housing of the Camden image has a decidedly Continental flavor not at all characteristic of daguerreotypes made in the American northeast.

To my mind, the presentation of this early image in a passe-partout mount would be sufficient evidence at least to attribute the portrait to a New Orleans operator, but further examination of the daguerreotype offered what I consider nearly irrefutable proof that the plate was made in that city. When the wooden backing of the exhibition frame was carefully lifted - without any disturbance to the original daguerreotype package-I was able to see clearly the paper seal which affixes the card cover of the daguerreotype plate to the back of the mount. Plain paper was commonly used for this type of seal; sometimes the photographer also would include his studio label here, or a more elaborately printed advertisement for his services. Often, one finds seals made of intriguing bits of scrap paper, and as with "binder's waste"-portions of manuscripts or printed materials used in the binding of early books - and these scraps can be as illuminating as the object itself. In the case of the Camden daguerreotype, most of the seal is comprised of strips of plain paper browned with age. A portion of the seal, however, is a $1 \frac{1 / 4}{4} 1$ inch scrap of what appears to be newsprint, in French, with the running head-“Le Messager"-fortuitously preserved.

"Le Messager" was a bi-lingual newspaper published upriver from New Orleans in the town of Bringier, in St. James Parish. ${ }^{8}$ Known as the "Organe des paroisses Saint-Facques et Saint Fean-Baptiste," its publisher was one C. A. Pieron, and it is believed to have been issued on a weekly basis from circa 24 July 1846 to circa 1860 . Incomplete runs of the paper exist in several Louisiana libraries; the file at Tulane University, however, is complete from 1848 to 1855 , and thus we can be sure that "Le Messager" was published continuously in the year that Whitman visited New Orleans. Whoever took the daguerreotype-or whoever worked in his studio-seems to have had an issue of the paper at 
hand to use in sealing Whitman's daguerreotype plate to the back of the mount. If there was ever a daguerreotypist's label on the back of the passe-partout mount, or on the frame, it is now lost; this small scrap of "Le Messager," however, serves almost as well as a label to locate the daguerreotype in the Louisiana of the 1840s that Whitman knew.

In the coming months, I intend to investigate the Camden daguerreotype's connections to New Orleans more fully, in hopes of discovering which daguerreotypist might have made the portrait-if indeed, his identity can ever be known. I wanted at this time, however, to share my observations with the Whitman scholarly community, for I feel that the evidence thus far points fairly conclusively to the daguerreotype's New Orleans origins. I would appreciate hearing from Whitman scholars with specialized knowledge of the author's New Orleans activities who might aid me in this search.

\section{Sotheby's, Inc., New York}

\section{NOTES}

1 I wish to thank Christian M. Bethmann, Superintendent I, Lebanon State Forest, New Jersey State Park Service, for so graciously allowing me to inspect the Camden daguerreotype. I would also like to thank Grant Romer, Photographic Conservator, International Museum of Photography at the George Eastman House, Rochester, New York, for discussing with me the terminology and construction of the passe-partout mount; and especially Michael Deas, author of The Portraits and Daguerreotypes of Edgar Allan Poe, for speedily providing me with information on "Le Messager."

2 The portrait is sometimes reproduced in Henry S. Saunders, Whitman Portraits (Toronto, 1922) as \#1.1; the Walt Whitman Quarterly Review, Volume 4, Nos. 2-3, Fall/Winter, 1986-1987, reproduces it as the second portrait from the decade of the 1840s. See also Justin Kaplan, Walt Whitman: A Life (New York, 1980), plate 6; Henry Seidel Canby, Walt Whitman: An American (New York, 1943), plate IV; and the Godine edition of Walt Whitman, Specimen Days (Boston, 1971), 124.

$3 W W Q R$ places the portrait in the early 1840s, when Whitman worked on the Aurora, and tentatively suggests John Plumbe, Jr., as the photographer. Kaplan captions the picture as "Walt Whitman in the 1840s at about age twenty-five." Canby also attributes the plate to Plumbe and describes it as "Walt Whitman in the 1840s or the earliest 1850s," "probably taken while he was editor of The Brooklyn Eagle."

4 For a special Whitman issue of Seaport Magazine (New York: South Street Seaport Museum, Winter, 1991), I was asked to contribute a general article on Whitman and the daguerreotype. In that article, I followed Whitman scholarship in attributing this early image to a New York photographer of the 1840s; I regret that I was not able to examine the Camden plate until after that article went to press.

5 A daguerreotype is commonly described in terms of its plate size-e.g., half-plate, quarter-plate, sixth-plate-rather than its dimensions in inches or centimeters. The "whole plate" supplied to daguerreotypists by manufacturers of photographic equipment measured about $6 \frac{1 / 2}{2} \times 8^{1 / 2}$ inches; smaller plates approximated a rough division of the whole plate into halves, quarters, and the like. 
6 Passe-partout mount is the terminology used in referring to a mount, or mat, with its central portion cut out to receive a picture. This opening is referred to as the mount or mat "window."

7 Cf. Margaret Denton Smith and Mary Louise Tucker, Photography in Neww Orleans: The Early Years, 1840-1865 (Baton Rouge, 1982), Chapters 1 and 2 (pp. 8-52), and especially the biographical checklist of New Orleans photographers, 151-171. This is the best and most comprehensive study of early New Orleans photography to date. The litany of French and German names in the biographical checklist is fascinating: Boucher, Bouny, Bourges, Boutevillian, Camille, Censier, Constant, Daliet, Dauboin, Dumoulin, Enful, Fleischbein, Guay, Heidingsfelder, Lilienthal, Moissenet, Pointel Du Portail, Schleier, Treihl, to name but a few.

8 The Louisiana State Newspaper Project Printout, April, 1990 (Baton Rouge, 1990), 159. 